\title{
PKM USAHA KECIL DI KAWASAN BUKIT KASIH KANONANG MINAHASA
}

\author{
Robby Joan Kumaat ${ }^{1}$, Debby Ch. Rotinsulu ${ }^{2}$, Daisy S. M. Engka ${ }^{3}$ \\ ${ }^{1,2,3}$ Ekonomi Pembangunan Fakultas Ekonomi dan Bisnis Unsrat, Manado Indonesia \\ E-mail koresponden : kumaatjoan@gmail.com
}

\begin{abstract}
ABSTRAK
Usaha Kecil adalah usaha yang berskala kecil, memiliki modal kecil dan cakupan pasar yang kecil pula. Keterbatasan modal dan cakupan pasar merupakan hal yang lumrah karena dalam perjalanan untuk menjadi besar butuh proses dan waktu. Keterbatasan Modal yang dimiliki merupakan kendala utama untuk pengembangan usaha. Begitu juga dengan Usaha Kecil yang ada di Kawasan Bukit Kasih Kanonang Minahasa. Keterbatasan Modal merupakan masalah dari Mitra Usaha kecil yang ada di Kawasan Bukit Kasih Kanonang, serta keterbatasan SDM dalam mengakses permodalan lewat Perbankan dengan penyusunan Proposal Kredit Usaha. Metode PKM ini yakni Penyuluhan untuk meningkatkan pengetahuan dan Pemahaman dari mitra tentang Pentingnya Permodalan dalam pengembangan usaha,Mengkakses modal dari pihak Perbankan serta pelatihan pembuatan proposal kredit usaha dengan khalayak sasaran mitra PKM yakni usaha kecil di kawasan Bukit Kasih Kanonang. Target Luaran yang dihasilkan berupa peningkatan pengetahuan dan pemahaman mitra PKM, serta Publikasi Artikel dalam jurnal Ilmiah, dan berita media online.
\end{abstract}

Kata kunci : usaha kecil; produktivitas: wisata

\section{PENDAHULUAN}

Kawasan Bukit Kasih Kanonang merupakan suatu kawasan Objek wisata Religi yang berada di Desa Kanonang Kawangkoan. Objek wisata Alam yang terletak di pegunungan ini menawarkan panorama yang indah dari atas puncak. Diseputaran kawasan Bukit Kasih Kanonang ini terdapat usaha-usaha kecil milik masyarakat sekitar. Terdapat Kios-kios/rumah makan dengan sajian makanan atau pun jajanan yang bisa dinikmati oleh pengunjung. Terdapat juga para penjual yang menjajakan berbagai cendramata yang bisa dijadikan oleholeh bagi yang berkunjung ditemnpat ini. Berikut ini Gambar usaha kecil yang ada di kawasan Bukit Kasih Kanonang. Setiap usaha oleh pemiliknya memiliki kerinduan untuk lebih maju dan berkembang, begitu juga dengan usaha kecil di Kawasan Bukit Kasih Kanonang. Keterbatasn Modal untuk pengembangan usaha menjadi factor kendala. Oleh Karena itu tim Pengabdian dari Fakultas Ekonomi dan Bisnis UNSRAT merasa terpanggil untuk membantu memecahkan masalah dari mitra PKM yakni pemilik usaha kecil lewat kegiatan PKM.

Berdasarkan Analisis situasi yang ada yakni yang diperoleh lewat wawancara awal yakni keterbatasan pengetahuan usaha kecil dalam penyusunan proposal kredit dalam rangka untuk pengembangan usaha dengan mengakses modal dari Perbankan. Berdasarkan analisis situasi dari Kelompok usaha kecil ,telah teridentifikasi permasalahan yang dihadapi. Oleh karena itu kami Tim Pengabdian pda Masyarakat dari Fakultas Ekonomi dan Bisnis UNSRAT Manado terpanggil untuk membantu memecahkan maslah yang di hadapi mitra PKM yakni usaha kecil di Kawasan Bukit Kasih Kanonang. Kegiatan PKM ini merupakan implementasi dari Tri Dharma Perguruan Tinggi yang ke 3 yaitu Pengabdian Pada Masyarakat. 


\section{KAJIAN LITERATUR}

UMKM adalah singkatan dari usaha Mikro kecil dan menengah. UMKM adalah salah satu bagian penting dari perekonomian suatu negara maupun daerah, begitu juga dengan negara indonesia ukm ini sangat memiliki peranan penting dalam lajunya perekonomian masyarakat. UMKM ini juga sangat membantu negara/pemerintah dalam hal penciptaan lapangan kerja baru dan lewat ukm juga banyak tercipta unit unit kerja baru yang menggunakan tenaga-tenaga baru yang dapat mendukung pendapatan rumah tangga. Selain dari itu UMKM juga memiliki fleksibilitas yang tinggi jika dibandingkan dengan usaha yang berkapasitas lebih besar. Ukm ini perlu perhatian yang khusus dan di dukung oleh informasi yang akurat, agar terjadi link bisnis yang terarah antara pelaku usaha kecil dan menengah dengan elemen daya saing usaha, yaitu jaringan pasar. Terdapat dua aspek yang harus dikembangkan untuk membangun jaringan pasar, aspek tersebut.

Kinerja nyata yang dihadapi oleh sebagian besar usaha terutama mikro, kecil, dan menengah (UMKM) di Indonesia yang paling menonjol adalah rendahnya tingkat produktivitas, rendahnya nilai tambah, dan rendahnya kualitas produk. Walau diakui pula bahwa UMKM menjadi lapangan kerja bagi sebagian besar pekerja di Indonesia , tetapi kontribusi dalam output nasional di katagorikan rendah. Hal ini dikarenakan UMKM, khususnya usaha mikro dan sektor pertanian (yang banyak menyerap tenaga kerja), mempunyai produktivitas yang sangat rendah. Bila upah dijadikan produktivitas, upah ratarata di usaha mikro dan kecil umumnya berada dibawah upah minimum. Kondisi ini merefleksikan produktivitas sektor mikro dan kecil yang rendah bila di bandingkan dengan usaha yang lebih besar.

Untuk meningkatkan daya saing UMKM diperlukan langkah bersama untuk mengangkat kemampuan teknologi dan daya inovasinnya. Dalam hal ini inovasi berarti sesuatu yang baru bagi si penerima yaitu komunitas UMKM yang bersangkutan. Kemajuan ekonomi terkait dengan tingkat perkembangan yang berarti tahap penguasaan teknologi. sebagian terbesar bersifat STATIS atau tidak terkodifikasi dan dibangun di atas pengalaman. Juga bersifat kumulatif (terbentuk secara 'incremental' dan dalam waktu yang tertentu). Waktu penguasaan teknologi ini bergantung pada sektor industrinya (sector specific) dan proses akumulasinya mengikuti trajektori tertentu yang khas.

Di antara berbagai faktor penyebabnya, rendahnya tingkat penguasaan teknologi dan kemampuan wirausaha di kalangan UMKM menjadi isue yang mengemuka saat ini. Pengembangan UMKM secara parsial selama ini tidak banyak memberikan hasil yang maksimal terhadap peningkatan kinerja UMKM, perkembangan ekonomi secara lebih luas mengakibatkan tingkat daya saing kita tertinggal dibandingkan dengan negara-negara tetangga kita seperti misalnya cina dan Malaysia. Karena itu kebijakan bagi UMKM bukan karena ukurannya yang kecil, tapi karena produktivitasnya yang rendah. Peningkatan produktivitas pada UMKM, akan berdampak luas pada perbaikan kesejahteraan rakyat karena UMKM adalah tempat dimana banyak orang menggantungkan sumber kehidupannya. Salah satu alternatif dalam meningkatkan produktivitas UMKM adalah dengan melakukan modernisasi sistem usaha dan perangkat kebijakannya yang sistemik sehingga akan memberikan dampak yang lebih luas lagi dalam meningkatkan daya saing daerah. Berikut ini adalah beberapa langkah yang bisa dilakukan untuk mengembangkan kemampuan dan keterampilan kita dalam meningkatkan UMKM yang dimiliki:

1. Pelaku UMKM harus memiliki jiwa kepemimpinan dalam dirinya

Walaupun Anda masih memulai UMKM dan belum memiliki seorang karyawan, Anda tetap harus menanamkan jiwa kepemimpinan dalam diri Anda, sehingga ketika nantinya memiliki karyawan Anda dapat memimpin karyawan tersebut dengan baik. Kemampuan Anda dalam memimpin, merencanakan, mengatur, dan menjalankan sebuah usaha tentunya akan memiliki peranan yang sangat penting dalam perkembangnan usaha. 
2. Pelaku UMKM Harus Mau Belajar Tentang Management

Pengetahuan tentang Management adalah hal yang sangat penting untuk dimiliki oleh seorang pelaku UKM. Dengan modal knowledge management, Anda akan mampu mengoptimalkan sumber daya yang ada dalam bisnis Anda, dan dapat mengurangi resiko kerugian yang mungkin terjadi.

3. Pelaku UMKM harus melakukan marketing dan branding

Salah satu penyebab kegagalan sebuah UKM adalah tidak melakukan marketing dan branding secara maksimal. Dua faktor ini adalah sangat penting dalam tumbuh kembangnya sebuah usaha baik skala besar ataupun skala kecil. Sebaiknya Anda menciptakan sebuah logo dan juga nama perusahaan yang mudah diingat oleh orang lain, dan juga melakukan promosi agar UKM Anda semakin dikenal oleh masyarakat luas. Kita jangan pernah lupa bahwa sebagus apapun produk yang Anda jual bila tidak didukung oleh kegiatan promosi yang baik, orang tidak akan mengenalnya.

4. Pelaku UMKM Harus Mampu Beradaptasi

Pasar yang semakin luas dan pertumbuhan UMKM yang semakin banyak tentunya akan menciptakan banyak tantangan. Seorang pelaku UMKM harus jeli dalam memperhatikan segala peluang dan hambatan yang mungkin datang ke hadapan Anda, dan dapat mengambil keputusan dan bertindak dengan cepat. Kemampuan dalam menghadapi persaingan yang semakin ketat dan dapat memenuhi permintaan konsumen yang semakin beragam akan membuat UMKM Anda dapat bertahan dan dapat berkembang ke arah yang lebih baik.

\section{METODE PELAKSANAAN}

Melihat permasalah yang dihadapi Mitra serta kemauan untuk maju dan mengembangkan usaha, maka Tim Program Kemitraan Masyarakat dari fakultas Ekonomi dan Bisnis UNSRAT terpanggil untuk melakukan kegiatan pengabdian pada masyarakat bagi Kelompok usaha Kecil di Kawasan Bukit Kasih Kanonang. Adapun metode yang ditempuh tim pengabdian yaitu metode pelatihan kepada para Usaha kecil. Berikut adalah tabel berupa metode yang disampaikan kepada peserta.

\begin{tabular}{|c|c|c|c|}
\hline No & Materi & $\begin{array}{l}\text { Alokasi } \\
\text { Waktu }\end{array}$ & Metode Pelatihan \\
\hline 1. & Manajemen Usaha & 30 Menit & $\begin{array}{l}\text { Ceramah } \\
\text { Diskusi/Tanya Jawab }\end{array}$ \\
\hline 2. & $\begin{array}{l}\text { Pentingnya permodalan untuk pengembangan usaha dan mengakses } \\
\text { modal dari perbankan }\end{array}$ & 30 Menit & $\begin{array}{l}\text { Ceramah } \\
\text { Diskusi/Tanya Jawab }\end{array}$ \\
\hline 3 & Praktek penyusunan proposal kredit & 45 Menit & Praktek \\
\hline 4. & Pembukuan sederhana & 30 menit & Praktek \\
\hline
\end{tabular}

Partisipasi mitra dari Kelompok Usaha yaitu menyediakan tempat pelaksanaan kegiatan, dan tim Program Kemitraan Masyarakat dari Fakultas Ekonomi dan Bisnis UNSRAT yaitu dengan menjadi nara sumber bagi kegiatan PKM dengan menjadi Nara sumber serta pendampingan dalam mengakses modal dari perbankan.

\section{HASIL DAN PEMBAHASAN}

Kegiatan Pengabdian pada masyarakat dengan mitra Usaha Kecil di Kawasan Bukit Kasih Kanonang dilaksanakan dengan beberapa tahapan kegiatan yakni dimulai dari survey awal dengan melakukan wawancara untuk mengetahui permasalahan mitra, kemudian tahap pelaksanaan kegiatan dengan metode penyuluhan/ ceramah, serta tahap akhir evaluasi dan monitoring. Selengkapnya Hasil yang dicapai pada pelaksanaan Program IbM ini dijelaskan sebagai berikut : 
1. Pada tahapan persiapan yakni survey di lapangan dapat diidentifikasi permasalahan dari mitra program PKM yakni Usaha kecil di Kawasan Bukit Kasih Kanonang. Dari permasalahan ini maka Tim membuat usulan pelaksanaan kegiatan / proposal proram IbM yang bertempat di Desa Kanonang 2 Kawasan Objek wisata Bukit Kasih. Usulan kegiatan ini diterima untuk dilaksanakan kegiatan program.

2. Pada Tahap pelaksanaan yakni Tim melakukan kegiatan penyuluhan dengan metode ceramah dan Tanya jawab. Pada pelaksanaan kegiatan ini Tim memberikan materi tentang Pentingnya modal kerja dalam memulai usaha / membuka usaha, Bagaimana mengakses modal dari pihak perbankan dan bagaimana menyusun proposal Kredit dari pihak perbankan. Peserta sangat senang sekali dengan adanya program PKM dari Tim Dosen Unsrat boleh mengunjungi mereka dan berbagi Ilmu Pengetahuan serta sharing pengalaman karena selain sebagai Dosen tetapi juga menjadi Pelaku Usaha.

3. Salah satu materi disajikan menyangkut permodalan Usaha, sehingga Tim juga memberikan materi bagaimana mengembangkan usaha dengan mengakses permodalan melalui pihak perbankan. Selain itu juga langsung diadakan praktek penyususnan proposal permohonan kredit dari pihak perbankan.

4. Tahap Evaluasi dan Monitoring

Untuk mengukur tingkat keberhasilan dari pelaksanaan program, maka dilakukan tahap evaluasi dan monitoring. Setelah dilaksanakan kegiatan penyuluhan oleh Tim, maka selanjutnya tim akan melakukan evaluasi apakah materi yang sudah diterima oleh peserta dapat dipahami betul dengan diterapkannya di lapangan pada usaha masing - masing. Luaran yang di capai pada pelaksanaan kegiatan Pengabdian Pada Masyarakat ini yaitu peningkatan Pengetahuan dan Pemahaman Mitra PKM melalui Materi yang disampaikan oleh Tim PKM, Peserta bisa Membuat Proposal Kredit, Publikasi Media Online, dan Artikel dalam jurnal IPTEKS.

\section{KESIMPULAN DAN SARAN}

\subsection{Kesimpulan}

Dari pelaksanaan kegiatan Pengabdian pada masyarakat ini , maka kesimpulan yang dapat diambil sebagai berikut :

1. Keinginan dari Pemilik usaha kecil sebagi mitra PKM untuk mengembangkan usaha mereka.

2. Keterbatasan Permodalan menjadi kendala untuk mengembangkan usaha.

3. Usaha kecil yang menjadi mitra PKM belum pernah mendapat tambahan modal dari pihak perbankan.

\subsection{Saran}

Diharapkan materi yang telah disampaikan dalam kegiatan PKM bagi mkitra Usaha kecil di Kawasan Bukit Kasih Kanonang ,bisa dipraktekan oleh agar usaha yang dimiliki bisa lebih maju dan berkembang.

\section{DAFTAR PUSTAKA}

Irianto J, 1996. Industri Kecil dalam Prospektif Pembinaan dan Pengembangan, AUP.

Lasut Sharlotte, 1999. Peranan Bank Dalam Pengembangan Usaha Kecil di Kecamatan Tomohon: Skripsi FE UNSRAT Manado.

Nugroho Widi, 1997. Informasi Kredit Usaha Kecil: PT. Pustaka Binaman Presindo.

Sadoko Isono dkk, 1991. Pengembangan Usaha Kecil: Penerbit Ahatika Bandung.

Pemasaran, Jilid 1 dan 2. Jakarta: PT. Indeks Kelompok Gramedia.

DR.H.Mulyadi Nitisusatro 2010, Kewirausahaan dan Manajemen Usaha Kecil

DR. Suryana MSi 2001, Kewirausahaan dan Manajemen Usaha Kecil, Salemba Empat 